DOI https://doi.org/10.36059/978-966-397-197-1/49-67

\title{
INFORMATION AND ADVERTISING DISCOURSE AS A PHENOMENON OF CULTURE
}

\section{Horban Yurii}

\section{INTRODUCTION}

Advertising becomes one of the aesthetic and cultural dimensions of the everyday life's culture, is closely embedded in mass culture, acquires an extremely sharp artistic impulse of the expressive type, and in this dimension becomes a separate, independent form of art with a huge budget, a large impact on the mass. Therefore, in the mass culture it has a special place, and in the post-Soviet culture advertising, on the one hand, helps to exist more effectively such media as television, show business, variety, and on the other becomes political advertising.

Television came later, and the poster discourse in the early periods of television was not as developed as it is now. By itself, advertising becomes not only the carrier of business strategies that exist now in the space of art-business, variety, show-business. Advertising was an element of propaganda and was equal to propaganda discourse. The post-totalitarian space that emerged during the rebuilding era needs more democratic advertising. Advertising messages take signs of performance type, theatricalize, become more serial, form advertising presentations. Typologically, this manifests itself in the fact that advertising is differentiated by genre characteristics: outdoor advertising, advertising in transport, advertising verbal type, advertising on radio, television, advertising as inserts in informational messages, works of art, in particular in television. This first caused shock then got used to the inserts and it turned out that this type of advertising discourse is the most effective. The commercialization and widespread press of advertising space shows that advertising is not just a "trade engine»", it is a certain regulator of mass culture, of the culture of everyday life as such.

The culture becomes impregnated advertising so much that teens begin to sing the slogans, advertising songs are included in the children's life. Advertising discourse grows so much in consumer fibre that it acts as a certain norm of cultural consumption. Without advertising, we no longer think of our existence. We promote ourselves, we become 
subjects of advertising discourse, we see no other role in communication than presentational-gaming.

\section{Social Advertising: Mechanisms of Impact}

Advertising is extremely diverse in ideology, presentation styles, and propaganda values. Under its influence, the worldview of people can become unsystematic, contradictory. For these reasons, advertising is seen as an important factor in the formation of morals, lifestyles and behaviours of children and young people who do not have the experience to critical comprehension of information. Advertising acts as a mechanism of persuasion and influence, and this influence has both positive and negative aspects. It creates false, unnecessary or harmful needs, directs the person to meet psychophysiological needs, increase prestige, but indirectly diminishes the significance of satisfying spiritual, intellectual needs, the role of intangible values. ${ }^{1}$

It is necessary to start the specification of information and advertising technologies in the most topical advertising discourse - social advertisement. It is social advertising that is more free in terms of the artistic potential of the advertising image. The goal-setting effect of advertising as a certain socio-pragmatics is the most dynamic system of the advertising message. However, the very name "social advertising" has not yet acquired a final definition. Any advertising is social, but when it comes to social advertising, it is, above all, advertising that disturbs, exposes social woes, phenomena, personifies them, if they need to be personalized. Or, on the contrary, in a certain person all the troubles of society are found and also an alternative way of changing the path of development, both society and personality is found.

Social advertising is the most dramatic about the conflict of objection and call for the attachment to certain values that are absolutely essential to everyone. The degrees of freedom of disposition and challenge are characterized in such a way as to achieve the greatest degree of contrast. That is, the subject of social advertising is not only a social individual, as is sometimes considered, not a society in a particular problem field but the human race as a whole. Namely, it is the horizon, the actor and the

${ }^{1}$ Hrabchak O. V. (2015) Sotsialna reklama ta yii rol u protsesakh samorehuliatsii suspilstva [Social advertising and its role in the processes of self-regulation of society]. Zbirnyk naukovykh prats Kamianets-Podilskoho natsionalnoho universytetu imeni Ivana Ohiienka. Seriia: Sotsialno-pedahohichna, vol. 24, pp. 44-52. 
actant of social action. The act of social advertising is defined in the general discourse, where the rules and regulations for resolving the crisis are universal. But there is a paradox: the genus does not act. It does not even contemplate. Genus is a limiting abstraction of a person or ancestor, who lives in real time and space, behaves in a particular environment.

The carrier of text in social advertising is a social information of a special type, attributable features of which are: publicistic style, publicity and promotion. ${ }^{2}$ This is the meaning of the text's presentation, which is formally an advertising message and meets the criteria of advertising, and substantially meets the criteria of publicistic style. A sign such as publicity for social advertising text is variable. Its manifestation means explication of the initiating subject of advertising activity, which is not always characteristic of social and advertising discourse. The publicistic style of the information presented in the text of a social media advertisement means an urgency explaining social problems. In this sense, the text of social media advertising is conceived as one of the mechanisms for constructing social problems. The problem category becomes a constant in the social-advertising discourse.

O. Melnyk states: "Advertising of information presented in the text of display social advertising is understood as the ability to pass representative information through the basic modules of advertising influence: segmentation, positioning, image, branding. Therefore, the name of the brand implicitly manifested in the text's structure of display social advertising and, accordingly poorly implemented in the process of the influence of such basic module as branding becomes necessary to reconsider the role, which grows in the process of promotion of socially significant ideas, positions and image of the social object advertised, which in this case perform compensatory function". ${ }^{3}$ The latter statement is extremely important. Brand as a trademark, as a guarantee of quality, does not play a leading role in social advertising. Any subject of the

${ }^{2}$ Melnik O. A. (2010) Sotcialnaia reklama: sposoby predstavleniia sotcialnoi informatcii [Social advertising: ways of presenting social information]. Proceedings of the Zhurnalistika: vzaimodeistvie nauki i praktiki (Russia, Rostov-na-Donu, 2010). Rostov-na-Donu, pp. 168-176.

${ }^{3}$ Melnik O. (2010) Tekst sotcialnoi reklamy v SMI: sposoby modelirovaniia informatcii [The text of social advertising in the media: ways of modelling information] (Abstract of $\mathrm{PhD}$ Dissertation). Voronezh: Voronezhskii gosudarstvennyi universitet. 
discourse is already a generic entity. And so the problem of branding disappears by itself.

That is, we can say that the manifestation of contemporary social problems is defined as a contrastive disposition, where good and evil are polarized. And, in fact, the very nomination of social advertising falls into the circle of similar nominations: social propaganda, sociallyoriented advertising, socially-responsive advertising, non-commercial advertising, public advertising, social-advertising discourse, etc. Therefore, all this, we will say, the nominative forbearance of social and advertising discourse only emphasizes its uncertainty. Therefore, the broad scope of the definition of the category "social advertising" in itself testifies only to the fact that society here acts as a mask, as a metaphor for a completely different issue. The person in the society, the person outside the society, the person as a generic being who fits in and does not fit into the society, produces an ideological complex of social advertising, which is religious in essence. "Religare" is a linking of people, the linking to the absolute - to the absolute good that eliminates metaphysical evil, exposes metaphysical guilt or conversely lifts it to the pedestal. These are the mechanisms that implicitly work in social advertising

It can be said that most of those who study social advertising consider it either in terms of sociological roles and functions, or political concepts, sometimes say that social advertising is connected with the fact that in culture it imitates folklore, archaic consciousness etc. The main thing is that social advertising as a mechanism of suggestion, influence has a clear journalistic direction (i.e. focused on the public) with its clearly defined syntagmatic (spatial articulation), which forces the design of social advertising to concentrate their messages, bring them to the aphoristic boundaries of self-determination. The extremes of the advertising message (verbal, visual) are in contact, and the transgression of all boundaries indicates that for all the phenomenological implications of the advertising image that determine the social problem, there is another phenomenon - a harmonious, self-sufficient image of a man.

Therefore, this type of advertising is not popular. It is rather marginal, but its marginality indicates that it needs more attention than the advertising of goods and services, where the problem of segmentation, positioning, branding is already sufficiently solved, and the strategy of integrated marketing communications overcomes the situation of goods' promotion in the market. In social advertising, there is no promotion of goods on the market. There is a need to treat social ulcers. Thus, the 
manifestation of social issues, its actualization in terms of imaginative realities, moreover, the visualization and aggressive definition of the problem in verbal discourse makes it possible to sharpen realities that are counterfactual. That is, to deny the destructive reality at the level of the metaphysical deep foundations of its origin and to offer not radical treatments, but radical ones, which give the possibility that one will be different. That is, an institutional-discursive approach, when such an institution, as social advertising, has its discourse, requires the definition of a certain ideal model of communication, formed by this advertising. The text of the discourse of social advertising has its communicative specificity, its semiotic reality, which presents and manifests social problems and shapes the needs of the target audience in search of information about their means of elimination or transformation into another problem which can be overcome.

The verbal-visual markers of social advertising are insufficient to make sense of social advertising as a whole. These are just phenomenological signs. Behind them, there is the polymodality of the image, the absolute of the ideal, the absoluteness of life and the denial of death, the denial of the disease, degradation, stagnation. One of the most important principles of the discourse of social advertising is the contrast, the juxtaposition of the two components as a dialogical counterfactual reality. Most often they are death and life, illness and a healthy way of life, degradation and development, disharmony and harmony. They correspond to the desired ideal categories: life, health, success, ideal, harmony, etc. If these categories remain at the level of abstract juxtaposition, they do not solve anything. We need to find a form of communicative presentations, a manifestation of a social problem, which becomes a sort of harmonization manifestation as a phenomenon (artefact) of eliminating a problem, and transforming it into another problem that can be overcome because it is not so dramatic as to require such intense attention.

Therefore, the problem of social advertising dispositions lies not so much in binaries, oppositions of positions, but in seeking dispositions as a system of contradictions, but reconciliation by intensifying a social problem, which in the verbal-visual context of social advertising discourse is defined as the semantic continuum of the radical elimination of evil. Instead of being associated with "nothingness" (the antithesis of beingness), an image of creation emerges, transforming nothing into a true, holistic being of a man. This is always the utopian path. It more often leads to visioning, suggestion. Sometimes this path in the artistic 
dimension becomes a romantic manifestation of the author's selfrealization, but social advertising always actualizes creativity, actualizes the need to be human. Social advertising does not flatten corners, smooth them, do not suppress the problem, and, on the contrary, exacerbates. It tries to find a positive solution from any negativity.

K.-O. Apel, a communications systems theorist, states: "The possibility of such an understanding of criteria, models, standards of correct decision in all human situations implies that speech understanding in every possible language game is a priori linked with the rules which can be established not by the way of "convention" but conversely, make the convention possible. These meta-rules of all conventionally established rules belong, in my opinion, not to certain language games or life-forms, but to a transcendental language game, or to an unrestricted communicative community". ${ }^{4}$ This is a good example that suggests that language consensus is mediated by the consensus of the communicators' arrangements.

In social advertising, we have not just a verification of certain meanings of life, but an event. That is, the figurative reality of the problematized being presented on a certain stage. Problematized on the stage of the problem, on the stage of society, on the stage of figurative reality, above all. And here it is important to apply the category "act". Everyone who participates in discourse becomes actants. That is, they stipulate this act. They become actors, the leaders of its temporality. The act of presenting a problem can be a one-off, solve all problems in a moment. But it can eliminate them in the future and never resolve. The range of temporalities from one moment to eternity, from the solution and not the solution of the problem at all - this is the distance in which the dispositive of the discourse of social advertising is formed. This dispositive is not a concern for itself, according to M. Foucault, it is not a problem of thinking about a purposeful-rational solution. It is rather aesthetic, visionary, mystical. Thus, sometimes something that has the prerequisite for consensus or some kind of agreement at the level of imaginative representations and imaginative abilities of the advertising message's actor becomes able to solve problems, to be the carrier of an eternal, holistic human being.

4 Yermolenko A. M. (1999) Komunikatyvna praktychna filosofiia [Communicative practical philosophy]. Kyiv: Líbra, p. 31. 
K.-O. Apel raises the problem of ethics, the responsibility of humanity as a whole in a state of ecological crises, the threat of nuclear war, tries to put forward certain tenets of responsibility Homo sapiens, which gives the opportunity to reconstruct or construct certain communicative actions. ${ }^{5}$ That is, it is new rationality of ethics of information and communication messages, where the normative conditions are argued from the point of view of the universal. But the general, one way or another, implies a rational statement. It can be said that such rationalization of the universal is, of course, modern construction and, in the context of postmodern consciousness, does not work, or becomes another construct, another postulate of the communicative ethos. However, from the point of view of the one who models this ideal, it is very important for the comprehension of the contextual and communicative act, which is based on the rationality and universal attitude of the person to the world. It is an out-of-contract, that is, transcendental (ideal - in the thesaurus of German practical philosophy) is a real ingredient of communication that precedes any consensus, by any rational, irrational, any other solution, which are possible in one or another society.

A. Yermolenko writes: "Modern western social science and philosophy, exploring the phenomena of "late" capitalism in terms of "social pathology", "anomie", "unmanageable complexity", "lack of legitimation", are trying to look for ways to overcome the social crisis. Their concepts seek to open up new forms of social integration, reconciling personal and public interests, individual and common goals and values. Many Westerners, including German philosophers and sociologists in the last third of the twentieth century, have put forward new paradigms of philosophical and sociological theory. One such paradigm, after "being" and "consciousness," is a communication paradigm that relies on transcendental (ideal) speech pragmatics, defining one of the most influential trends in modern Western thought communicative philosophy". 6

There is a certain linguistic-hermeneutic, pragmatic turn. We can say that this is enough for the ideal model of social advertising to acquire its

${ }^{5}$ Apel K.-O. (1999) Situatsiia liudyny yak etychna problema [Human situation as an ethical problem]. Yermolenko A. M. Komunikatyvna praktychna filosofiia [Communicative practical philosophy]. Kyiv: Líbra, pp. 231-255.

6 Yermolenko A. M. (1999) Komunikatyvna praktychna filosofiia [Communicative practical philosophy]. Kyiv: Líbra, p. 19. 
general features. On the basis of perfect (transcendental) pragmatics, communication based on speech actions or events, in our case consensus of verbal and visual in advertising image, it is possible to define a certain model that can be described as a given imperative for solving the problem, where from the position of the generic subject constants for solving social problems are given. But they are not solved "here" and "now" and are eliminated in the perspective of figurative decisions and proposals.

Advertising in terms of humanization of communication acts as a contextual and content method of person's inclusion into the environment. So D. Smith gives an elaborate phenomenology of advertising discourse: "For the first time, a person looks at an advertising message and does not see it.

For the second time, he or she doesn't notice him either.

For the third time, he or she is aware of his presence.

Fourth, it is hard to remember where he or she saw it.

For the fifth time, he or she reads the ad.

For the sixth time, he or she captures this message with the eyes among other messages.

For the seventh time he reads it all over and says, "Oh, my God!"

For the eighth time he proclaims, "Well, this damn product again!"

The 9th time she thinks, "What is this thing?"

For the tenth time he or she thinks to ask her neighbor if he has bought such a thing.

For the eleventh time, he wonders how this thing can generate advertising revenue.

For the twelfth time, he concludes that this thing is probably worth something.

For the thirteenth time, he concludes that he may need this thing.

For the fourteenth time, he remembers dreaming about this thing all her life.

For the fifteenth time, he is in a hurry that he cannot afford to buy this thing.

For the sixteenth time, he tells himself, "The time will come - and I will definitely buy myself this thing."

For the seventeenth time, he plans to buy this thing.

For the eighteenth time, he curses his impoverishment.

For the nineteenth time, he counts his money. 
For the twentieth time, he again sees ads and buys this thing, or orders his wife to buy it". ${ }^{7}$

When creating social advertising, it's important to consider the age and social characteristics of your target audience. If the recipients of social advertising are youth, it is important that the source of distribution must be the Internet (including social networks) and less - television. Information promotions of social advertising should be directed not only to the object of influence but also to its environment. Rational social advertising should include information about the harmful effects of alcohol, tobacco or drugs on the human body, as well as the difficulties encountered in addiction, problems that can potentially arise in various areas of life. Emotional social advertising is more influential when using positive motivation while stimulating a sense of responsibility and obligation. It is especially important to use short-term inclusion of emotional advertising in rational advertising in order to increase the recipient's attention. ${ }^{8}$

\section{Advertising as a Means of Promotion and Regulator of Mass Culture}

Social advertising has genetically grown out of propaganda. Advertising in a totalitarian culture was not possible; its role was played by a propaganda discourse that was consistent with the mythologeme of an ideally developed society. "It has got better to live, it has become to live more fun" - this brand can be seen in various modifications: in a poster, a picture of Plastov, where the farmers gathered in the field for breakfast with a poster hung over the table with a well-known formula of life. Cheerful from their work people did not notice that they live in a concentration camp, did not notice that it was one more another step and you would stay there forever. Even H. Shchedrovytskyi, a philosopher who gave many theories of design and business games, wrote that when they were young, they did not notice the tragedy of the time, and if somebody was taken into paddy wagons, then they deserved it. The youth danced, everyone went to visit, walked in the

${ }^{7}$ Muzykant V. L. (1998) Teoriia i praktika sovremennoi reklamy [Theory and practice of modern advertising] (Pt. 1). Moskow: Evraziiskii region, p. 39.

${ }^{8}$ Gasiuk M. (2019) Sotsialna reklama yak zasib profilaktyky adyktyvnoi povedinky osib yunatskoho viku [Social advertising as a means of preventing adolescent addictive behavior]. Visnyk Prykarpatskoho universytetu, vol. 22, pp. 67-76. 
evening, all night, and did not even see all that then was told to everyone everywhere.

The advertising world has adequate connotations. In general, advertising as a way of identity is extremely archaic. K. Salnikova, who studied the motives of identification in advertising, writes that advertising is primarily about appealing to the organic senses, to food, sex, enjoyment in general and perceives any event of purchase, acquisition or event of consumption of values in the form of advertising discourse as a certain sublime device, like the world of heroization any consumption.

O. Salnikova writes: "Advertising constantly encourages the use of products, to consume them in all substantial, essential forms. This is a general excitement for advertising. The direct implementation of the excitatory vector into action is the motive of eating. In the advertising plots, any food topic is natural, the absorption of the product is alleged without residue, in its pure form, in the truest sense, that is, absorption as such. <....> The beauties and the handsome of all stripes eat, covering their eyes and almost ecstatic. The grand plans, lit by the delight of faces, are interspersed with the oversized plans of erotic moving lips. Characters of other roles, especially commoners and commoners, eat "deliciously" and joyfully, with moderate and excessive physiological optimism. Families eat in harmonious minor or major, perfectly amicable. Food is a pleasure that is accessible to all. And so food is "unity," a deliciousness that unites all potential audiences from birth to food. People with different looks, gender, age, social status, character, profession, intelligence - they are all equally created to eat something".

However, it is important to note that advertising as a hidden mode of propaganda of the Stalin era was in fact such, it was a heroized ethos of consumption, but the subject of this consumption was necessarily a Soviet worker, in Brezhnev's propaganda discourse he became a winner of the communist winner. Actually, then, there were heroes of labour, unlike the heroes that had existed before, as military figures, winners in the war. That is, the discourse of heroizing reality was not always purely political. It was aesthetic, had its advertising connotations. Advertising as a form of art was heroic propaganda, most often in poster discourse.

${ }^{9}$ Salnikova E. V. (2001) Estetika reklamy. Kulturnye korni i leitmotivy [Aesthetics of advertising. Cultural roots and keynotes]. Moskow: Aleteiiam, pp. 17-18. 
The radio also carried advertising, but not as clearly and clearly as the posters did.

J. Baudrillard states: "The cruelty and sometimes the brutality of the use of advertising technologies are no longer adequate. In this sense, violence and nonviolence, like all antinomic phenomena, play the role of neglect in a society that wants to see itself and sees itself as hyperactive and contented with rockers, on the one hand, and hippies, on the other, are revealed, for example, in their profound characteristics as a society passivity and violence. They take over the hidden violence of this society to turn it against it, deepening it to paroxysm. Others deepen the latent passivity behind the façade of society's additivity, deepening it to the practices of rejection and complete individuality, forcing it thus to deny itself in its relations with its own logic". 10

Advertising sells time, the political electorate, goods as an image, as a person, sells a flash image of a fashionable dress that is dressed to one or another figure of an advertising communicator. There is always an effect of identity totalizing, which is done simply by "pinching" things, by "eating" an advertising image. Haptic eating, the search effect of the deepest identification systems simplifies the communicative discourse and homogenises it. The homogeneity of advertising is so well defined that it even crosses the line between male and female. Advertising becomes androgynous. Androgynism of advertising further universalizes information transmission systems. This is especially felt in the postSoviet space: a purely feminine type of attraction, glamour does not work, because a person is in a difficult position, she can not buy everything.

The male impulse of willpower impulse in advertising is reduced because society suffers from new political fights, new rich people, millionaires, so there is androgynism in one or another genre dimension, in one or another figurative flash image, which presents either male or female in the hypostasis of the consumption's subject. Therefore, advertising should not be regarded as a service, as an auxiliary phenomenon. Advertising becomes a total discourse of communication. Why is this happening?

10 Bodriiiar Zh. (2006) Obshchestvo potrebleniia. Ego mify i struktury [Consumption society. Its myths and structures] (Trans. Samarskaia E. A.). Moskow: Respublika; Kulturnaia revoliutciia, p. 228. 
The need for political advertising is extraordinary, because it plays political games, is carried out in the mask of political carnivals. Political advertising presents the discourse of power, though it is oriented towards humane and social role definitions of actions and image of a person in society. Ye. Romat states: "It should be noted that political advertising is an extremely important but not the main tool of this system. With a wide variety of means of power struggle, advertising plays a whole ancillary role, due to its specific responsibilities, the political market is one of the few areas where the importance and effectiveness of advertising are inferior to public relations (political relations) even in countries with developed democracies, rather than marketing tools, but above all administrative resources, are quite effective".

The genealogy of advertising discourse as a dynamic, expressive and aesthetic reality has several intentions: to "override" others, which is carried out by the complaint - to deny the information that exists nearby; rejection is the first axiom of advertising; this is an extremely urgent use of politics; in fact, it has the natural function of "overlapping" all other media of advertising discourse, that is, those who carry out messages, articulate verbal information. Then, when the screaming effect has already been reached, it is important to keep the information at the level of the perception threshold so that it does not tire, produce a certain context of interest, not be too intentional.

If such a problem did not exist in the age of totalitarianism, advertising as an enclave of propaganda was elementary, there was no question of its authenticity, then in the post-Soviet space, the first of the main tasks of advertising is the need to be relevant. Advertising is always focused on replacing the subject with a flash image, a brand, a trend. Thus, the perfect item is always advertised. However, the function of advertising is not to make a buyer or other thing or service, it is merely an incentive to buy.

These aspects of the information field became extremely polyphonic in the post-Soviet space. The genres of advertising are polarizing, and there is a demand for social advertising: drug addiction, alcohol, depression, disbelief require not only treatment of the targeted client, but also certain measures of special intervention in the soul of the person. Political advertising is breaking all records. The worthy poster with Hroysman's "I am Ukrainian" is an oxymoron, but at the time it looked

${ }^{11}$ Romat E. V. (2008) Reklama [Advertising] (7 ed). St. Petersburg: Piter, p. 144. 
authentic because there was a peculiar presentation of national politics as a broad political identity that went beyond ethnic morality. As time goes by, the policies change and the posters of recent times seem rather naive.

N. Luman notes: "The translation of the selection results is determined in the strict sense of the word, that selective achievement is reproduced in simplified, abstracted from initial constellations conditions. Such simplification and abstraction require symbols that replace the specific foundations of the original context in the breeding chain, so communicative tools evolve into symbolically generalized codes for the purpose of general orientation. Each of the subsequent phases of the process remains therefore in the selection to the same extent as the previous one. The means of communication thus combine the commonality of orientation and the identity of selection. Power as a communicative means functions only under these conditions". 12

The communicative advertising space is becoming more and more indicative of the poetics of postmodern art, including such broad relationships as land art, which is followed by an advertising campaign about red, green, and blue rocks. On the one hand, it is the definition of industrial markers of nature, and on the other, it is the advertising of paints. Also involved are performance advertising stunts, where advertising turns into a particular myth design.

Advertising becomes one of the aesthetic and cultural dimensions of the culture of everyday life and is closely integrated into mass culture. Advertising begins to work in the realm of protest simulators, including putting up non-profit political posters in unauthorized places, production areas of the product runs counter to the advertising discourse in general, but by contrast, it updates its attention. The media and advertising activity becomes extremely aggressive, which immediately offends the recipient. There is a need to humanize advertising messages, to create certain communicative ethics of advertising. P. Ricker writes: "Speech violence should not only be regarded as a formal truth but also spoken of as the imperative of the commandment not to kill at any time, even when it cannot be fulfilled. The one who keeps this commandment always recognizes the other as a reasonable being and in every way respects him". 13

\footnotetext{
${ }^{12}$ Luman N. (2001) Vlast [Power]. Moskow: Praksis, p. 17.

${ }^{13}$ Riker P. (1995) Navkolo polityky [Around politics]. Kyiv: „D. L.”, p. 146.
} 
The role of PR companies in advertising cannot be overlooked. It defines the areas of external and internal communication. F. Sharkov, A. Rodionov note: "External communications combine the organization with the outside world, while internal ones determine the specificity and quality of the organization's activity. The internal relationship is the creation of the image of the leader, the image of the organization and team, including corporate identity, creation of corporate culture (team, work, creativity, life, the system of interaction, personnel issues). External communications are the maintenance of constant contacts with partners, including potential ones, communication with the media, communication with the public society, and government institutions, the actualization of international relations, advertising, preparation for crisis situation and liquidation of crisis". ${ }^{14}$

We can point to certain strategies that are implemented in the advertising culture as effective mechanisms for presenting and communicating information. Thus, this is a balance of presentation and management. Kh. Kaftandzhyiev defines codes for the presentation of information: "The codes of sign systems are a system of rules by which we use signs when we create and perceive messages.

They are mainly rules of alphabetic, semantics, syntax and programming.

The alphabet code is a system of rules by which we structure the alphabets of sign systems. Semantic code is a system of rules by which we structure and express meaning.

The syntax is a system of rules by which we combine characters into texts.

The pragmatic code is a system of rules that help to use the signs depending on the relevant communication situation". ${ }^{15}$

The means of communication are changing, but the communicativesemiotic context remains the same. A balanced presentation also plays a significant role in the integration of advertising technology, as equipment prices go down, it is easy to imagine a time when the walls of the exposition will consist entirely of digital panels. However, traditional

${ }^{14}$ Sharkov F. I. (2007) Reklama i sviazi s obshchestvennostiu: kommunikativnaia $i$ integrativnaia sushchnost kampanii [Advertising and public relations: the communicative and integrative nature of campaigns]. Moskow: Akademicheskii Proekt; Ekaterinburg: Delovaia kniga, pp. 164-165.

${ }^{15}$ Kaftandzhiev Kh. (2006) Garmoniia v reklamnoi kommunikatcii [Harmony in advertising communication] (Trans. Kirova S.). Moskow: EKSMO, p. 34. 
materials and demonstrations will continue to be used to create a balance of information and communication opportunities for information presentation.

The last important aspect of advertising is management, technological maintenance of media technology, where content can be quickly transformed from the most modern means of imagination to the most routine. It is important to program these changes as specific cyclical fluctuations in the advertising space, using the ability to eliminate obsolete items, not to mention regular updating of positioning systems. That is, the information field is exposed, but it can be said that these problems belong to the culture as a whole. Each of the identified areas of the promotional presentation performs a specific function based on its own tasks. After all, the temporality of information presentation, the focus on not stagnating the information every day, was a place oriented to clear codes of its transmission, and at the same time figuratively effective and attractive - this is the supremacy of all cultural advertising practices.

Therefore, advertising brings to its culture its own distinctive locus. Advertising is focused on the collapsed expressive image presentation of the image, unfolds it in infinity (social advertising), focused on the balanced presentation of information (sociopragmatics of advertising messages), which tries to complain (criticize) all other information messages, to consolidate its own image. Advertising performs a real mediating function of the imaginative construction (verbal, visual, pictorial, subject). Actually, the information construction as a pattern, the gestalt of the advertising message characterizes the unity of all certain aspects, their cultural and historical integrity.

Which of the three identified areas of advertising is dominant in the post-Soviet space? There is no clear answer to this question. Since it is not rhetorical, it can be argued that the systemogenesis of the culture of the post-Soviet space activates one or another component in one or another period of integration or vice versa. So now, in the context of the war between Russia and Ukraine, advertising is dominated by the worst meaning of propaganda discourse, everything that is advertised is advertised, but not what can be defined as the deep fundamental values of the modernity's human.

This advertising is closer to passion-advertising, advertising as a system of manipulative technologies of consciousness. If in retrospect, look at the times of perestroika, there was dominant advertising as a broad stream of formation of the desired identity, transformation and presentation of Western images. If we look a little further in retrospect to 
the "fracture" of consciousness (perestroika), then the psychological type of communicative technologies, which formed the guidelines of the nonconform worldview of the 60s, which is still returning today, dominated here. It returns as a concern, but returns already in completely different overtones, other figurative installations. Postmodern identity in the communicative space is formed in completely unexpected circumstances of total play and irony, falling into the field of wide fluctuations in identity, where the recipient is simultaneously a player, consumer, tourist, walker, according to Z. Bauman.

If we use the metaphor of $\mathrm{Z}$. Bauman of tourism as a certain type of sociocultural identity, it is worth pointing that in the age of globalization it is already total, global tourism as consumption of values in a limited time range. Advertising as a type of identity, in the face of globality also falls into the model space of "global tourism". Thus, the consumer of advertising discourse moves the globe quickly, at all airports he is met by a standard set of fast service - coffee, sandwich, juices. Advertisements of all resorts are full of blue sky and yellow sand.

That is, global tourism, as a certain echo of the levelling of culture and suggestion of consumption patterns characteristic of one area, the socalled highly developed countries, copy other cultures, in the reality of advertising messages, focus on the totalization and homogenization of tastes. The consumer model as a "global tourist" is tourism with unlimited advertising opportunities, where an extensive exhibitor indicates that advertising in the age of globalization finds the limits and horizons of local satisfaction of the needs of the selected, and the intensive component indicates that this type of consumption of cultural values, by all means, tries to avoid homogenization.

It seeks to fill in the gaps that globalization of culture as its unification carries out. That is, the yellow sand and blue sky are lit by the cultural space of slogans, flash images that give the aura of another being to natural destinations (attractive landscapes). Global tourism as a type of cultural identity is the reality of consumption of the compensatory type, which can be framed within the so-called metamodernity - wide fluctuations between the extremes of cultural formation.

\section{CONCLUSIONS}

Culture of information and advertising presentations as a kind of art is defined in the ontological realities, which were formed institutionally in the environment space, subject world. So, as an advertisement focused on the environment, transport, the reality with which a person meets every day, ontologically concentrated in the material indirect or re- 
introduction of all other audial, visual, symbolic, iconic forms of communication to the code of a thing, substance mediated is the deepest intuition of advertising social action. Thus, a thing, a symbol, a sign, an image present an ontology of advertising messages as a humandimensional space, a reality that has artistic features. The art of advertising is defined as the ability to convey information, the skill to determine its priority, and as creativity - to involve the creative realities of the identity of the individual and the subject of advertising discourse.

Therefore, a broader integrative locus, mechanism of cultural formation, should be identified than cultural practices, including advertising. In our view, such a broad integrative mechanism is virtual reality in all its connotations, all modes of its presentation, systems of functioning and self-determination of man as a being in the space of virtus of modern culture. Thus virtus man has no mortal form of existence. Consumer man receives the guarantor of immortality with the purchase of a product or service. In essence, it is an archaic code of cultural creation - the elimination of death, but it is not brought to the surface, because this archetype is mercilessly corrupted in the context of modern socio-pragmatic communication. Immortality of the kind Man appears in portraits - in the faces of people who have already reached it. The cyborg warriors, victims of catastrophes, legendary artists, and singers combine in one broad channel of information flow every day and every night of the culture of everyday life, where advertising plays the role of director, arranger and seductive image.

All the above facts make it possible to say that the culture of information and promotional presentations tries to absorb the cultural tradition, on the one hand, and gives the opportunity to escape from the brutal, primitive reality of complaint, the same politics, the need to survive, to compete for life, etc. The whole complex is ontologically immersed in ethics and aesthetics. It can also be noted that advertising has a reduced aesthetic reality, in particular, "tragic" as an aesthetic category in it is almost undefined. We will not see the tragic videos in the commercial, they are more focused on the comic than the tragic.

\section{SUMMARY}

Modern cultural, social and economic processes create the conditions for the existence of advertising space in a new quality, namely as a global axiological translator, which in turn forms a new anthropological type of person, embracing certain traits caused by the peculiarities of modern consumer society. The purpose of the article is investigating the features of the advertising discourse functioning; determining the 
dominant sphere of advertising in the post-Soviet space. The scientific novelty is determined by the fact that the study broadens and deepens the idea of advertising as a phenomenon of culture, demonstrating the importance of a comprehensive study of cultural, anthropological and philosophical aspects of advertising. Conclusions. The art of advertising is defined as the ability to convey information, the skill to determine its priority, and as creativity to tap into the creative realities of the identity of the individual and the subject of advertising discourse. So, as advertising, which is focused on the environment, the transport, the reality with which a person meets every day, is focused on substantially mediating or translating all other audio, visual, symbolic, symbolic forms of communication into a code of things, real-world mediation is the deepest intuition of social actions of advertising. Thus, a thing, a symbol, a sign, an image present an ontology of advertising messages as a human-dimensional space, a reality that has artistic features. All the above facts make it possible to say that the culture of information and promotional presentations tries to absorb the cultural tradition, on the one hand, and on the other gives an opportunity to escape from the brutal, primitive reality of reclamation.

\section{REFERENCES}

1. Apel K.-O. (1999) Situatsiia liudyny yak etychna problema [Human situation as an ethical problem]. Yermolenko A. M. Komunikatyvna praktychna filosofiia [Communicative practical philosophy]. Kyiv: Libra, pp. 231-255.

2. Bodriiiar Zh. (2006) Obshchestvo potrebleniia. Ego mify $i$ struktury [Consumption society. Its myths and structures] (Trans. Samarskaia E. A.). Moskow: Respublika; Kulturnaia revoliutciia. (in Russian)

3. Gasiuk M. (2019) Sotsialna reklama yak zasib profilaktyky adyktyvnoi povedinky osib yunatskoho viku [Social advertising as a means of preventing adolescent addictive behavior]. Visnyk Prykarpatskoho universytetu, vol. 22, pp. 67-76.

4. Hrabchak O. V. (2015) Sotsialna reklama ta yii rol u protsesakh samorehuliatsii suspilstva [Social advertising and its role in the processes of self-regulation of society]. Zbirnyk naukovykh prats KamianetsPodilskoho natsionalnoho universytetu imeni Ivana Ohiienka. Seriia: Sotsialno-pedahohichna, vol. 24, pp. 44-52.

5. Kaftandzhiev Kh. (2006) Garmoniia v reklamnoi kommunikatcii [Harmony in advertising communication] (Trans. Kirova S.). Moskow: EKSMO. (in Russian) 
6. Luman N. (2001) Vlast [Power]. Moskow: Praksis. (in Russian)

7. Melnik O. (2010) Tekst sotcialnoi reklamy v SMI: sposoby modelirovaniia informatcii [The text of social advertising in the media: ways of modelling information] (Abstract of $\mathrm{PhD}$ Dissertation). Voronezh: Voronezhskii gosudarstvennyi universitet.

8. Melnik O. A. (2010) Sotcialnaia reklama: sposoby predstavleniia sotcialnoi informatcii [Social advertising: ways of presenting social information]. Proceedings of the Zhurnalistika: vzaimodeistvie nauki $i$ praktiki (Russia, Rostov-na-Donu, 2010). Rostov-na-Donu, pp. 168-176.

9. Muzykant V. L. (1998) Teoriia i praktika sovremennoi reklamy [Theory and practice of modern advertising] (Pt. 1). Moskow: Evraziiskii region. (in Russian)

10. Riker P. (1995) Navkolo polityky [Around politics]. Kyiv: „D. L.”. (in Ukrainian)

11. Romat E. V. (2008) Reklama [Advertising] (7 ed). St. Petersburg: Piter. (in Russian)

12. Salnikova E. (2012) Fenomen vizualnogo. Ot drevnikh istokov $k$ nachalu XXI veka [The phenomenon of the visual. From ancient sources to the beginning of the XXI century]. Moskow: Progress-Traditciia. (in Russian)

13. Salnikova E. V. (2001) Estetika reklamy. Kulturnye korni $i$ leitmotivy [Aesthetics of advertising. Cultural roots and keynotes]. Moskow: Aleteiia. (in Russian)

14. Sharkov F. I. (2007) Reklama $i$ sviazi s obshchestvennostiu: kommunikativnaia $i$ integrativnaia sushchnost kampanii [Advertising and public relations: the communicative and integrative nature of campaigns]. Moskow: Akademicheskii Proekt; Ekaterinburg: Delovaia kniga. (in Russian)

15. Yermolenko A. M. (1999) Komunikatyvna praktychna filosofiia [Communicative practical philosophy]. Kyiv: Libra. (in Ukrainian)

\section{Information about the author: Horban Yurii, orcid.org/0000-0001-5837-4409}

$\mathrm{PhD}$ in Cultural Studies, Associate Professor

Kyiv National University of Culture and Arts 36, Ye. Konovaltsia Str., Kyiv, 01133, Ukraine 